UDC 519.21

DOI: 10.20535/1810-0546.2016.4.71649

\author{
O.A. Tymoshenko \\ National Technical University of Ukraine "KPI”, Kyiv, Ukraine

\section{GENERALIZATION OF ASYMPTOTIC BIHAVIOR OF NONAUTONOMOUS STOCHASTIC DIFFERENTIAL EQUATION}

Background. The study of the asymptotic behavior of solutions of stochastic differential equations is one of the main places in many sections of insurance and financial mathematics, economics, management theory since stochastic differential equations, as an effective model of random process is the basis for the study of random phenomena.

Objective. In this paper we consider the almost sure asymptotic behavior of the solution of the nonautonomous stochastic differential equation.

Methods. We proposed a method to study the $\psi$-asymptotic properties of a solution of a stochastic differential equation by comparison with a solution of an ordinary differential equations obtained by dropping the stochastic part. We also use of the theory of pseudo-regularly varying functions.

Results. We investigate the asymptotic behavior of solutions stochastic differential equations and establish sufficient conditions that provide different types of asymptotic behavior of a random process.

Conclusions. Stochastic models approximate the real processes much better than deterministic ones, however, deterministic modelling has been preferred to stochastic one because of much greater ease of computability. The presented result enabled comparing properties of solution a stochastic differential equation with a solution of an ordinary differential equation.

Keywords: stochastic differential equation; Wiener process; asymptotic behavior.

\section{Introduction}

We study the problem of asymptotic behavior of a random processes. One of the most effective models of random processes is a stochastic differential equation, which arises in many problems in various areas such as the radiophysics, sound navigation and ranging, seismography, meteorology, evolution of biological populations, theory of signals and automatic control, filtration, econometrics, financial mathematics, and so on. Adding a stochastic process is very actual due to the uncertainty about future system development. Stochastic models approximate the real processes much better than deterministic ones.

The almost sure (a.s.) asymptotic behavior of solutions of one-dimensional autonomous stochastic differential equation is considered in [1-6].

The same problem was later considered in [7-9] for a more general stochastic differential equation $d \eta(t)=g(\eta(t)) \varphi(t) d t+\sigma(\eta(t)) \theta(t) d w(t)$, where $g$ and $\sigma$ are continuous positive functions, $\varphi$ and $\theta$ are continuous functions. Some sufficient conditions are obtained in [7-9] under which the exact order of growth of a solution $\eta$ is determined a.s. by a solution of the corresponding ordinary differential equation Moreover, the asymptotic equivalence of two solutions of stochastic differential equations with time-depended coefficients and that of the solutions of the corresponding ordinary differential equations is considered in [7-9].
In this paper we will consider some generalization of asymptotic equivalence of stochastic differential equations. Making use of the theory of pseudo-regularly varying functions, we find some sufficient conditions on $g, \varphi, \sigma, \theta$ and $\psi$, under which $\psi(\eta)$ can be approximated a.s. by $\psi(\mu)$, where $\mu$ is the solution of the ordinary equation $d \mu(t)=g(\mu(t)) \varphi(t) d t, \mu(0) \equiv b, b>0$.

\section{Research objective}

The objective of the research presented in this paper is to provide some sufficient conditions, under which the solutions of stochastic differential equations become almost nonrandom in the asymptotic sense.

\section{Assumptions and the main results}

Consider the stochastic differential equations

$$
d \eta(t)=g(\eta(t)) \varphi(t) d t+\sigma(\eta(t)) \theta(t) d w(t), t>0 .
$$

In the current paper we provide some sufficient conditions under which the solution of onedimensional stochastic differential equation, whose coefficients are the product of a function of the spatial variable and the function of time, satisfies the asymptotic relation 


$$
\lim _{t \rightarrow \infty} \frac{F_{1}(\eta(t))}{F_{2}(t)}=1 \text { a.s., }
$$

where $F_{1}, F_{2}$ are some nonrandom functions.

The paper is organized as follows. We start with finding conditions under which the following relation holds true

$$
\lim _{t \rightarrow \infty} \frac{G(\eta(t))}{\Phi(t)}=1 \text { a.s. }
$$

since

$$
\begin{aligned}
& G(x)=\int_{b}^{x} \frac{d s}{g(s)}, x \geq b, \\
& \Phi(t)=\int_{0}^{t} \varphi(u) d u, t \geq 0 .
\end{aligned}
$$

Then the main result of the paper, $\psi$-asymptotic equivalence of solutions of nonautonomous stochastic differential equation and ordinary differential equation is obtained. It means that

$$
\lim _{t \rightarrow \infty} \frac{\psi(\eta(t))}{\psi(\mu(t))}=1 \text { a.s. }
$$

for given function $(\psi(x), x \in \mathbb{R})$.

Note that a result similar to (3) is proved in [6] for an autonomous stochastic differential equation.

Asymptotic equivalence of solutions of nonautonomouse stochastic differential equation and ordinary differential equation. In this section we consider the stochastic differential equations (1) and discuss, under which conditions the solution $\eta$ of this equation satisfies the relation (2).

We denote by $\mathrm{Ce}\left(\mathrm{Ce} e_{+}\right)$the class of all continuous (and positive) functions and by $\mathrm{Ce}^{1} \quad\left(\mathrm{Ce}_{+}^{1}\right)$ the class of all continuously differentiable (and positive) functions and assume that $g \in C e_{+}$, $\varphi \in C e$ and $\sigma \in C e_{+}, \theta \in C e$ are such that equation (1) has a continuous solution $\eta$.

In the sequel, we make use of the following four conditions

$$
\begin{gathered}
\lim _{x \rightarrow \infty} G(x)=\infty ; \\
\Phi(t)>0, t>0 ; \\
\lim _{t \rightarrow \infty} \Phi(t)=\infty ; \\
\limsup _{t \rightarrow \infty} \frac{\Phi_{+}(t)}{\Phi(t)}<\infty \text { for }
\end{gathered}
$$

$$
\Phi_{+}(t)=\int_{0}^{t}|\varphi(u)| d u, t \geq 0 .
$$

We recall the sufficient conditions for (2) (see [8]).

Theorem 1. Let $g \in C e_{+}, \varphi \in C e$ and $\sigma \in C e_{+}$, $\theta \in C e$ be such that (1) has a continuous solution $\eta$ and conditions (4)-(7) hold. Assume that

$$
\sum_{k=0}^{\infty} \frac{\int_{0}^{2^{k+1}} \theta^{2}(s) d s}{\Phi_{+}^{2}\left(2^{k}\right)}<\infty .
$$

We also assume the following conditions:

a) the function $\frac{\sigma}{g}$ is bounded;

b) the function $g$ is continuously differentiable, and its derivative $g^{\prime}(x), x \in \mathbb{R}$, is such that

$$
\begin{gathered}
\lim _{t \rightarrow \infty} \frac{\int_{0}^{t}\left|g^{\prime}(\eta(s))\right| \theta^{2}(s) d s}{\Phi_{+}(t)} \\
=0 \text { a.s. on the set }\left\{\lim _{t \rightarrow \infty} \eta(t)=\infty\right\} .
\end{gathered}
$$

Then (2) holds a.s. on the set $\{\lim \eta(t)=\infty\}$.

An application of Theorem 1 is considered in Example 1. The result of this Example 1 is used in Example 3 to illustrate the main result of this paper.

Example 1 (Population growth model). Stochastic differential equation

$$
\begin{gathered}
d \eta(t)=r(t) \eta(t) d t+\beta \eta(t) d w(t), \\
t \geq 0 ; \eta(0) \equiv 1,
\end{gathered}
$$

describes population growth (see [10]), where $\eta$ is the size of population at time $t ; r$ is relative growth rate of the population that depends on time; $w$ is a Wiener process; $\beta \in(0 ;+\infty)$.

Let $r \in C e$. Denote $R(t)=\int_{0}^{t} r(s) d s$ and assume that

$$
\begin{gathered}
R(t)>0, t>0, \\
\lim _{t \rightarrow \infty} R(t)=\lim _{t \rightarrow \infty} \int_{0}^{t} r(s) d s=\infty, \\
\lim _{t \rightarrow \infty} \frac{t}{R(t)}=0 .
\end{gathered}
$$


Solution of the equation, which describes population growth is

$$
\eta(t)=\exp \left\{\left(R(t)-\frac{1}{2} \beta^{2} t\right)+\beta w(t)\right\} .
$$

So from (12) we conclude that $\eta$ tends to infinity a.s. with $t \rightarrow \infty$. Really,

$$
\begin{aligned}
& \lim _{t \rightarrow \infty} \eta(t)=\lim _{t \rightarrow \infty} \exp \left\{\left(R(t)-\frac{1}{2} \beta^{2} t\right)+\beta w(t)\right\} \\
= & \lim _{t \rightarrow \infty} \exp \left\{t\left(\frac{R(t)}{t}-\frac{1}{2} \beta^{2}+\beta \frac{w(t)}{t}\right)\right\}=\infty \quad \text { a.s. }
\end{aligned}
$$

It is clear that $\Phi(t)=R(t)$. Note, by (12), (13), the function $\Phi(t)$ satisfy conditions (5), (6).

Since $g(x)=x$, we obtain (6), i.e.

$$
\lim _{x \rightarrow \infty} G(x)=\lim _{x \rightarrow \infty} \ln x=\infty .
$$

It is also clear, if (12) holds, then condition (8) holds too

$$
\sum_{k=0}^{\infty} \frac{\int_{0}^{2^{k+1}} \theta^{2}(s) d s}{\Phi_{+}^{2}\left(2^{k}\right)}=2 \sum_{k=0}^{\infty} \frac{2^{k}}{R^{2}\left(2^{k}\right)}<\infty,
$$

and for $g^{\prime}(x)=1$ we get the relation (9). Then, by Theorem 1, we have (2), i.e.

$$
\lim _{t \rightarrow \infty} \frac{G(\eta(t))}{\Phi(t)}=\lim _{t \rightarrow \infty} \frac{\ln (\eta(t))}{R(t)}=1 \quad \text { a.s. }
$$

-asymptotic equivalence for nonautonomouse stochastic differential equation with time-dependent coefficients. It is not always easy or even impossible to determine the asymptotic behavior of the stochastic differential equation solution. In this case it is advisable to consider the so-called $\psi$-asymptotic equivalence of solutions in the sense of $(3)(\psi$ is a given positive continuously differentiable function on $(0, \infty)$, strictly increasing to infinity as $x \rightarrow \infty)$.

Sufficient conditions for the $\psi$-asymptotic equivalence of solutions stochastic differential equation (1) and corresponding ordinary differential equation are presented in this section. The result generalizes those in [6].

A partial case of (3) corresponds to the problem of approaching solutions $\eta$ and $\mu$ considered by A.P. Krenevich [11, 12], A.M. Samoylenko, O.M. Stanzhytskiy [13], and A.M. Samoylenko, O.M. Stanzhytskiy, I.G. Novak [14].
The approximation in [12-15] means that

$$
\lim _{t \rightarrow \infty}(\eta(t)-\mu(t))=0 \quad \text { a.s. }
$$

If $\psi(x)=e^{x}$, then (3) reads as follows:

$$
\lim _{t \rightarrow \infty} \frac{e^{\eta(t)}}{e^{\mu(t)}}=1 \quad \text { a.s., }
$$

which is equivalent to (13). Thus, the problem of approximation of solutions is a particular case of the problem of asymptotic equivalence considered in the current paper.

Put

$$
\begin{gathered}
G^{(\psi)}(\cdot)=G\left(\psi^{-1}(\cdot)\right), g^{(\psi)}(\cdot) \\
=g\left(\psi^{-1}(\cdot)\right) \psi^{\prime}\left(\psi^{-1}(\cdot)\right),
\end{gathered}
$$

where $G$ is as in (6), the function $\psi^{-1}(u)$, $u \geq \psi\left(x_{0}\right)$ is inverse to $\psi$, and $\psi^{\prime}$ is the first derivative of $\psi$.

Observe that $\left(G^{(\psi)}(t), t \geq b_{k}\right)$ is the inverse function of $\psi(\mu(\cdot))$. For example, if $\psi(\cdot)=\ln (\cdot)$, then $G^{(\mathrm{ln})}(\cdot)=G\left(e^{(\cdot)}\right)$ and $g^{(\mathrm{ln})}(\cdot)=g\left(e^{(\cdot)}\right) e^{-(\cdot)}$. If $\psi(x)=x$, then $G^{(\psi)}=G$ and $g^{(\psi)}=g$.

Note that one of the basic assumptions in this paper is that the solution of the stochastic differential equation (1) a.s. increases indefinitely and tends to infinity.

Remark 1 (see, [16]). Solution $\eta$ of equation (1) with $\lim _{t \rightarrow \infty} \eta(t)=\infty$ a.s. if, for example, the function $g, \varphi, \theta, \sigma$ satisfy the following assumptions:

1. $\lim _{x \rightarrow \infty} \tilde{B}(x)=\lim _{x \rightarrow \infty} \int_{0}^{x} \frac{d y}{\sigma(y)}=\infty \quad$ a.s.;

2. $\lim _{T \rightarrow \infty} \frac{1}{\sqrt{2 T \ln \ln T}} \int_{0}^{T} \inf _{x \in R}(\tilde{a}(t, x)) d t>1$, where

$\tilde{a}(t, x)=-\frac{\theta^{\prime}(t)}{\theta^{2}(t)} \int_{0}^{x} \frac{d y}{\sigma(y)}+\frac{g(x) \varphi(t)}{\sigma(x) \theta(t)}-\frac{1}{2} \sigma^{\prime}(x) \theta(t) ;$

3. $\lim _{x \rightarrow \infty} \inf \theta(t)>0$.

Consider next three relations:

$$
\begin{gathered}
\lim _{t \rightarrow \infty} G(t)=\int_{b}^{\infty} \frac{d u}{g(u)}=\infty, \\
\liminf _{t \rightarrow \infty} \int_{t}^{c t} \frac{d u}{g^{(\psi)}(u) G^{(\psi)}(u)}
\end{gathered}
$$




$$
\begin{gathered}
=\liminf _{t \rightarrow \infty} \int_{\psi^{-1}(t)}^{\psi^{-1}(c t)} \frac{d u}{g(u) G(u)}>0 \text { for all } c>1, \\
\quad \lim _{c \downarrow 1} \limsup _{t \rightarrow \infty} \int_{t}^{c t} \frac{d u}{g^{(\psi)}(u) G^{(\psi)}(u)} \\
=\lim _{c \downarrow 1} \limsup _{t \rightarrow \infty} \int_{\psi^{-1}(t)}^{\psi^{-1}(c t)} \frac{d u}{g(u) G(u)}=0 .
\end{gathered}
$$

Theorem 2. Let $g \in C e_{+}, \varphi \in C e$ and $\sigma \in C e_{+}$, $\theta \in C e$ be such that equation (1) has a continuous solution $\eta ; \psi$ is a positive continuously differentiable function on $(0, \infty)$, strictly increasing to infty as $x \rightarrow \infty$. Assume that conditions (14) and (15) hold. Then

$$
\begin{aligned}
& \text { a) if } \lim _{t \rightarrow \infty} \frac{G(\eta(t))}{\Phi(t)}=1 \quad \text { a.s., then } \\
& \lim _{t \rightarrow \infty} \frac{\psi(\eta(t))}{\psi(\mu(t))}=1 \quad \text { a.s. }
\end{aligned}
$$

b) if (16) holds, then

$$
\lim _{t \rightarrow \infty} \frac{G(\eta(t))}{\Phi(t)}=1 \quad \text { a.s. } \Leftrightarrow \lim _{t \rightarrow \infty} \frac{\psi(\eta(t))}{\psi(\mu(t))}=1 \quad \text { a.s. }
$$

The theory of the so-called PRV-functions developed in work [9] is used in the proof of Theorem 2.

Proof. By conditions (14), (15) and Theorem 4.4.1 (see, Section 4, p. 106, [9]), whith $f=G^{(\psi)}$ and $f^{\prime}=\frac{1}{g^{(\psi)}}$, we have that $G^{(\psi)}$ satisfies relation

$$
\liminf _{t \rightarrow \infty} \frac{G^{(\psi)}(c t)}{G^{(\psi)}(t)}>1 \text { for all } c>1 .
$$

Moreover, $G^{(\psi)}$ is continuous function, which is strictly increasing for large $t$. Hence, function $\left(G^{(\psi)}\right)^{-1}(\cdot)$ preserves the equivalence of functions. Therefore, by Theorem 6.1 (see, [6]), next relation follows

$$
\begin{gathered}
1=\lim _{t \rightarrow \infty} \frac{G(\eta(t))}{\Phi(t)}=\lim _{t \rightarrow \infty} \frac{\left(G^{(\psi)}\right)^{-1}(G(\eta(t)))}{\left(G^{(\psi)}\right)^{-1}((\Phi(t))} \\
=\lim _{t \rightarrow \infty} \frac{\psi\left(G^{-1}(G(\eta(t)))\right.}{\psi\left(G^{-1}(G(\mu(t)))\right.}=\lim _{t \rightarrow \infty} \frac{\psi\left(G^{-1}(G(\eta(t)))\right.}{\psi\left(G^{-1}(\Phi(t))\right.} \\
=\lim _{t \rightarrow \infty} \frac{\psi(\eta(t))}{\psi(\mu(t))} \quad \text { a.s. }
\end{gathered}
$$

Statement a) is proved.

In order to prove statement $b$ ) we assume that (16) holds. Then, by (14), (16) and Theorem 4.4.1 (see Section 4, p. 106, [9]), with $f=G^{(\psi)}$ and $f^{\prime}=\frac{1}{g^{(\psi)}}$, we have that $G^{(\psi)}$ is PRV function (see definition 3.3.1, p. 66, [9]).

Then, by conditions (14)-(16), and Lemma 7.2 (see, [6]), function $G^{(\psi)}(\cdot)=G\left(\psi^{-1}(\cdot)\right)$ preserves the equivalence of functions. So,

$$
\begin{gathered}
1=\lim _{t \rightarrow \infty} \frac{\psi(\eta(t))}{\psi(\mu(t))}=\lim _{t \rightarrow \infty} \frac{G^{(\psi)}(\psi(\eta(t)))}{G^{(\psi)}(\psi(\mu(t)))} \\
=\lim _{t \rightarrow \infty} \frac{G(\eta(t))}{\Phi(t)} \quad \text { a.s. }
\end{gathered}
$$

Statement b) is proved.

Let us return to the population growth model in Example 1.

Example 2. Consider stochastic differential equations from Example 1. By Theorem 1 (see Example 1), we have

$$
\lim _{t \rightarrow \infty} \frac{G(\eta(t))}{\Phi(t)}=1 \quad \text { a.s. }
$$

Consider the Cauchy problem for the ordinary differential equation corresponding to stochastic differential equation

$$
d \mu(t)=r(t) \mu(t) d t, t \geq 0 ; \mu(0) \equiv 1,
$$

where the unique solution is $\mu(t)=e^{R(t)}$.

Since functions $g=x, \quad \psi(x)=\ln x$, we get $G(x)=\ln x, \psi(x)=\ln x$. Moreover, $\psi^{-1}(x)=e^{x}, g^{(\psi)}(x)=$ $=g\left(\psi^{-1}(x)\right) \psi^{\prime}\left(\psi^{-1}(x)\right)=1, G^{(\psi)}(x)=x-1, x \geq 1$.

In this case,

$$
\begin{gathered}
\liminf _{t \rightarrow \infty} \int_{\psi^{-1}(t)}^{\psi^{-1}(c t)} \frac{d u}{g(u) G(u)}=\liminf _{t \rightarrow \infty} \int_{e^{t}}^{e^{c t}} \frac{d u}{u \ln u} \\
=\ln c>0 \text { for all } c>1 .
\end{gathered}
$$

And

$$
\lim _{c \downarrow 1} \limsup _{t \rightarrow \infty} \int_{\psi^{-1}(t)}^{\psi^{-1}(c t)} \frac{d u}{g(u) G(u)}=\lim _{c \downarrow 1} \lim \sup \ln c=0 .
$$

So (15) and (16) are satisfied. As all the conditions of Theorem 2 are fulfilled then

$$
\lim _{t \rightarrow \infty} \frac{\psi(\eta(t))}{\psi(\mu(t))}=1 \quad \text { a.s. }
$$


Remark 2. The result of Theorem 2 with $\psi(x) \equiv x$ coincides with the results of [8] for

$$
\lim _{t \rightarrow \infty} \frac{\eta(t)}{\mu(t)}=1 \text { a.s. }
$$

Here is a simple example.

Example 3. Consider stochastic differential equation

$$
\begin{gathered}
d \eta(t)=t^{\alpha}\left(1+\eta^{2}(t)\right)^{\gamma} d t \\
+\left(1+\eta^{2}(t)\right)^{\gamma} d w(t), t \geq 0 ; \eta(0) \equiv b,
\end{gathered}
$$

where $w$ is a Wiener process; $b$ is nonrandom positive constant, $0<\gamma<\frac{1}{2}, \alpha>0$.

Coefficients of the equation have the form $\varphi(t)=t^{\alpha}, \theta(t)=1, g(x)=\sigma(x)=\left(1+x^{2}\right)^{\gamma}$.

For $\alpha>0$ we have

$$
\sum_{k=0}^{\infty} \frac{\int_{0}^{2^{k+1}} \theta^{2}(s) d s}{\Phi_{+}^{2}\left(2^{k}\right)}=2 \sum_{k=0}^{\infty} \frac{2^{k}}{\left(2^{k}\right)^{2 \alpha+2}}<\infty .
$$

Function $\frac{\sigma}{g}=1$ is bounded. For $g^{\prime}(x)=$ $=2 \gamma x\left(1+x^{2}\right)^{\gamma-1}, \frac{1}{2}<1-\gamma<1$, we obtain

$$
\lim _{x \rightarrow \infty} g^{\prime}(x)=\lim _{x \rightarrow \infty} 2 \gamma \frac{x}{\left(1+x^{2}\right)^{1-\gamma}}=0
$$

and

$$
\lim _{t \rightarrow \infty} \frac{\int_{0}^{t} \theta^{2}(s) d s}{\Phi(t)}=\lim _{t \rightarrow \infty} \frac{(\alpha+1) t}{t^{\alpha+1}}=0<\infty .
$$

It follows that condition (9) holds.

We conclude, that for coefficients of equation (17) all conditions of the Theorem 1 hold. Therefore,

$$
\lim _{t \rightarrow \infty} \frac{G(\eta(t))}{\Phi(t)}=1 \quad \text { a.s. }
$$

Note, $g$ is regularly varying function with index $\alpha=2 \gamma<1$. Then, by (4) and statement 2.1 (see [3]) we get

$$
\liminf _{t \rightarrow \infty} \int_{t}^{c t} \frac{d u}{g(u) G(u)}>0 \text { for all } c>1 .
$$

Thus, by Theorem 2, with $\psi=x$ we have

$$
\lim _{t \rightarrow \infty} \frac{\eta(t)}{\mu(t)}=1 \text { a.s. }
$$

Finally, $\tilde{a}(t, x)$ for equation (17) has form:

$$
\tilde{a}_{1}(t, x)=t^{\alpha}-\gamma x\left(1+x^{2}\right)^{\gamma-1} .
$$

Since $\left[\tilde{a}_{1}(t, x)\right]_{x}^{\prime}=\gamma\left(1+x^{2}\right)^{\gamma-2}\left((1-2 \gamma) x^{2}-1\right)$, we obtain $x_{\min }=(1-2 \gamma)^{-\frac{1}{2}}$. Then

$$
\min _{x}\left[\tilde{a}_{1}(t, x)\right]=t^{\alpha}-\gamma \frac{(2-2 \gamma)^{\gamma-1}}{(1-2 \gamma)^{\gamma-\frac{1}{2}}}
$$

and

$$
\begin{gathered}
\liminf _{T \rightarrow \infty} \frac{1}{\sqrt{2 T \ln \ln T}} \int_{0}^{T} \inf _{x \in \mathbb{R}^{1}}\left[\tilde{a}_{1}(t, x)\right] d t= \\
=\liminf _{T \rightarrow \infty} \frac{1}{\sqrt{2 T \ln \ln T}}\left(\frac{T^{\alpha+1}}{\alpha+1}-\frac{T \gamma(2-2 \gamma)^{\gamma-1}}{(1-2 \gamma)^{\gamma-\frac{1}{2}}}\right)=\infty .
\end{gathered}
$$

It means that $\lim _{t \rightarrow \infty} \eta(t)=\infty$ a.s.

\section{Conclusions}

Notion of $\psi$-asymptotic equivalence of one dimentional nonautonomous stochastic differential equation solution and ordinary differential equation solution are proposed. It helps to compare behaviour of solutions in the case of unboundedness of difference between of them. Sufficient conditions of $\psi$-asymptotic equivalence of nonautonomous stochastic differential equation solutions and ordinary differential equation solutions are obtained.

The result of this type where the stochastic behavior is explained, albeit in the asymptotic sense, by the behavior of the deterministic component can be called ergodic theorem or strong law of large numbers.

Main results of this paper can be effectively used for the ergodicity and stability of stochastic processes are related to the construction of stochastic risk models and processes in actuarial mathematics. 


\section{List of literature}

1. Гихман И.И., Скороход А.В. Стохастические дифференциальные уравнения и их приложения. - К.: Наук. думка, 1982. $-610 \mathrm{c}$.

2. Keller G., Kersting G., Rosler U. On the asymptotic behavior of solutions of stochastic differential equations // Z. Wahrsch. Geb. - 1984. - 68. - P. 163-184.

3. Buldygin V.V., Klesov O.I., Steinebach J.G. The PRV property of functions and the asymptotic behavior of solutions of stochastic differential equations // Theory Probab. Math. Statist. - 2004. - 72. - P. 63-78.

4. Buldygin V.V., Klesov O.I., Steinebach J.G. On some properties of asymptotically quasi-inverse functions and their applications. I // Theory Probab. Math. Statist. - 2003. - 70. - P. 9-25.

5. Buldygin V.V., Klesov O.I., Steinebach J. On some properties of asymptotically quasi-inverse functions and their applications. II // Theory Probab. Math. Statist. - 2004. - 71. - P. 63-78.

6. On the $\varphi$-asymptotic behavior of solutions of stochastic differential equations / V.V. Buldygin, O.I. Klesov, J.G. Steinebach, O.A. Tymoshenko // Theor Stoch. Process. - 2008. - 14. - P. 11-30.

7. Булдигін В.В., Тимошенко О.А. Точний порядок росту розв'язків стохастичних диференціальних рівнянь // Наукові вісті НТУУ “КПІ”. - 2008. - № 6. - С. 127-132.

8. Buldygin V.V., Tymoshenko O. A. On the exact order of growth of solutions of stochastic differential equations with timedependent coefficients // Theor Stoch. Process. - 2010. - 16. - P. 12-22.

9. Псевдорегулярні функції та узагальнені процеси відновлення / В.В. Булдигін, К.-Х. Індлекофер, О.І. Клесов, Й.Г. Штайнебах. - K.: ТВІМС, 2012. - 441 c.

10. Oksendal B.K. Stochastic Differential Equations: An Introduction with Applications. Berlin: Springer, 2003.

11. Креневич А.П. Асимптотична еквівалентність розв'язків лінійних стохастичних систем Іто // Укр. мат. журн. - 2006. 10. - P. 1368-1384.

12. Креневич А.П. Асимптотична еквівалентність розв'язків нелінійних стохастичних систем Іто // Нелінійні коливання. 2006. - 2. - P. 213-220.

13. Самойленко А.М., Станжицький О.М., Якісний та асимптотичний аналіз диференціальних рівнянь 3 випадковими збуреннями. - К.: Наук. думка, 2009. - 335 с.

14. Самойленко А.М., Станжицький О.М., Новак І.Г. Про асимптотичну відповідність між розвязками стохастичних та звичайних рівнянь // Укр. мат. журн. - 2011. - 8. - С. 1103-1127.

15. Klesov O.I., Tymoshenko O.A. Unbounded solutions of stochastic differential equations with time-dependent coefficients // Annales Univ. Sci. Budapest., Sect. Comp. - 2013. - 41. - P. 25-35.

\section{References}

1. I.I. Gihman and A.V. Skorohod, "Stochastic differential equations and its applications. Kyiv, USSR: Naukova Dumka, 1982 (in Russian).

2. G. Keller et al., "On the asymptotic behavior of solutions of stochastic differential equations", Z. Wahrsch. Geb., vol. 68, pp. 163-184, 1984.

3. V.V. Buldygin et al., "The PRV property of functions and the asymptotic behavior of solutions of stochastic differential equations”, Theory Probab. Math. Statist., vol. 72, pp. 63-78, 2004.

4. V.V. Buldygin et al., "On some properties of asymptotically quasi-inverse functions and their applications. I", Theory Probab. Math. Statist., vol. 70, pp. 9-25, 2003.

5. V.V. Buldygin et al., "On some properties of asymptotically quasi-inverse functions and their applications. II", Theory Probab. Math. Statist., vol. 71, pp. 63-78, 2004.

6. V.V. Buldygin et al., "On the $\varphi$-asymptotic behavior of solutions of stochastic differential equations", Theor Stoch. Process., vol. 14, pp. 11-30, 2008.

7. V.V. Buldygin and O.A. Tymoshenko, "On the asymptotic stability of stochastic differential equations", Naukovi Visti NTUU KPI, no. 6, pp. 127-132, 2008 (in Ukrainian).

8. V.V. Buldygin and O.A. Tymoshenko, "On the exact order of growth of solutions of stochastic differential equations with time-dependent coefficients”, Theor. Stoch. Process., vol. 16, pp. 12-22, 2010.

9. V.V. Buldygin et al., Pseudo Regularly Varying Functions and Generalized Renewal Processes. Kyiv, Ukraine: TBiMC, 2012 (in Ukrainian).

10. B.K. Oksendal, Stochastic Differential Equations: An Introduction with Applications. Berlin, Germany: Springer, 2003.

11. A.P. Krenevich, "Asymptotic equivalence of solutions of linear stochastic Ito's systems", Ukr. Math. J., vol. 10, pp. 13681384, 2006 (in Ukrainian). 
12. A.P. Krenevich, "Asymptotic equivalence of solutions of nonlinear stochastic Ito's systems", Nonlinear Fluctuation, vol. 2, pp. 213-220, 2006 (in Ukrainian).

13. A.M. Samoylenko and O.M. Stanzhytskiy, Qualitative and Asymptotic Analysis of Differential Equations with Random Perturbations. Kyiv, Ukraine: Naukova Dumka, 2009 (in Ukrainian).

14. A.M. Samoylenko et al., "On asymptotic correspondence between conventional and stochastic solutions of equations", $U k r$. Math. J., vol. 8, pp. 1103-1127, 2011 (in Ukrainian).

15. O.I. Klesov and O.A. Tymoshenko, "Unbounded solutions of stochastic differential equations with time-dependent coefficients”, Annales Univ. Sci. Budapest., Sect. Comp., vol. 41, pp. 25-35, 2013.

\section{О.А. Тимошенко}

УЗАГАЛЬНЕННЯ АСИМПТОТИЧНОЇ ПОВЕДІНКИ НЕАВТОНОМНИХ СТОХАСТИЧНИХ ДИФЕРЕНЦІАЛЬНИХ РІВНЯНЬ

Проблематика. Вивчення асимптотичної поведінки розв'язків стохастичних диференціальних рівнянь посідає одне з чільних місць у багатьох розділах страхової та фінансової математики, економіки, теорії управління, оскільки стохастичні диференціальні рівняння як ефективна модель випадкового процесу є основою для дослідження випадкового явища.

Мета дослідження. Ми досліджуємо асимптотичну поведінку розв'язків неавтономних стохастичних диференціальних рівнянь.

Методика реалізації. Запропоновано метод для вивчення $\psi$-асимптотичних властивостей розв'язку стохастичного диференціального рівняння за допомогою розв'язку звичайного диференціального рівняння. При доведенні основних результатів використано теорію псевдорегулярно змінних фрункцій.

Результати дослідження. Встановлено достатні умови, за яких розв'язки стохастичних диференціальних рівнянь стають майже невипадковими в асимптотичному розумінні.

Висновки. Стохастичні моделі апроксимують реальні процеси набагато краще, ніж детерміновані, однак детерміновані задачі відрізняються більшою легкістю дослідження. Одержаний результат дав змогу порівняти властивості розв'язку стохастичного диференціального рівняння із властивостями розв'язку детермінованої задачі.

Ключові слова: стохастичні диференціальні рівняння; вінерівський процес; асимптотична поведінка.

\section{О.А. Тимошенко}

\section{ОБОБЩЕНИЕ АСИМПТОТИЧЕСКОГО ПОВЕДЕНИЯ НЕАВТОНОМНЫХ СТОХАСТИЧЕСКИХ ДИФФЕРЕНЦИАЛЬНЫХ УРАВНЕНИЙ}

Проблематика. Изучение асимптотического поведения решений стохастических дифференциальных уравнений занимает одно из основных мест во многих разделах страховой и финансовой математики, экономики, теории управления и т.д., поскольку стохастические дифференциальные уравнения как эффективная модель случайного процесса являются основой для исследования случайного явления.

Цель исследования. Мы исследуем асимптотическое поведение решений неавтономных стохастических диффреренциальных уравнений.

Методика реализации. Предложен метод для изучения ж-асимптотических свойств решения стохастического дифференциального уравнения с помощью решения обыкновенного дифференциального уравнения. При доказательстве основных результатов использована теория псевдорегулярно изменяющихся функций.

Результаты исследования. Получены достаточные условия, при которых решения стохастических дифференциальных уравнений становятся почти случайными в асимптотическом смысле.

Выводы. Стохастические модели аппроксимируют реальные процессы гораздо лучше, чем детерминированные, однако детерминированные задачи отличаются большей легкостью исследования. Представленный результат позволил сравнить свойства решения стохастического дифференциального уравнения со свойствами решения детерминированной задачи.

Ключевые слова: стохастические дифференциальные уравнения; винеровский процесс; асимптотическое поведение.

Рекомендована Радою

фізико-математичного факультету

НТУУ “КПІ"
Надійшла до редакції

20 травня 2016 року 